\title{
Misconception Profile of Prospective Physics Teachers Assessed from Various Representations of Electricity Subjects
}

\author{
Muhammad Zuhdi ${ }^{*}$, Ahmad Busyairi ${ }^{1}$ \\ ${ }^{1}$ Physics Education Dept. Education Faculty, University of Mataram, Mataram, Indonesia.
}

DOI: $\underline{10.29303 / \text { jossed.v2i1.490 }}$

\section{Article Info}

Received : October $5^{\text {th }}, 2020$

Revised : April 20th 2021

Accepted: April 24th, 2021

\begin{abstract}
Misconception is one of the important problems that often arise in education. The objective of this study is identify misconceptions in the subject of Electricty that occur in prospective teachers. The method used in this research is descriptive method. A total of 25 pre-service physics teacher candidates at a university in the Mataram City were involved in this study. The instrument used in this study was a three-tier test. This study use a total of 40 test items. These questions are classified into two types of representation, namely; verbal and figural. The results showed that $88.1 \%$ of prospective physics teachers had misconceptions on Kirchoff's first law, 94.8\% misconceptions on Kichoff's second law concept, $91.7 \%$ misconceptions on Ohm's Law concept and $85.9 \%$ on electrical sources concepts. The results of the study show that $72.3 \%$ of prospective physics teachers had misconceptions on verbal type questions and $84.2 \%$ misconceptions on figural types.
\end{abstract}

Keywords: verbal and figural; misconception; multiple representation; electricity.

Citation: Zuhdi, M., \& Busyairi, A. (2021). Misconception Profile of Prospective Physics Teachers Assessed from Various Representations of Electricity Subjects. Journal of Science and Science Education, 2(1), 33-37. doi:https://doi.org/10.29303/jossed.v2i1.490

\section{Introduction}

Physics is a branch of Natural Sciences (IPA) that studies various natural phenomena that occur in this universe. These natural phenomena are presented in the form of concepts, theories, and physical laws so that they can be easily accepted by the human mind (Kaniawati, 2017). The concept is a verbal sign that is used to represent the state of an object or natural phenomenon. Internal energy, heat, work, force, velocity, momentum, impulses and so on are examples of concepts found in physics.

Concept are fundamental agents to intellectual work. Concept learning is the identification of the concept attributes, which help generalize newly encountered examples and discriminate examples from non-example. The process of primitive categorization of objects is concept formation (Gafoor and Akhiles, 2008).

Concept in sciences can be divided in concrete concept and formal concept. Concrete concepts are those concept, which name classes of entities for which there are numerous perceptible instances. Formal concepts are those concepts that do not have perceptible instance (Herron, Cantu, Ward and Srinwan, 1977).

Conception is a person's description or understanding of a certain phenomenon. In fact, someone's description or interpretation of the same concept can be different. For example, the scientist's conception of heat is the amount of energy retained from an object at a high temperature to an object at a lower temperature. Unlike the scientist's conception, the conceptions that develop in students regarding the concept of heat are a form of energy possessed by objects with high temperatures. This student's conception is different from the concept established by the expert. There are two possibilities related to this student's conception, namely; the student's conception is less precise or even the student's conception is wrong because it is different from the scientist's conception which is considered the most correct than other 
conceptions. This misunderstanding is usually called a misconception.

One of the problems that is often encountered in the world of education, especially in physics is the existence of misconceptions in students. Hikmawati \& Sutrio (2019) say that misconceptions are concepts that are believed to be true by students, but are not in accordance with the truth of the concepts recognized by experts. Misconception is a term that indicates a difference in thinking between the concepts that students have and the concepts defined by the expert (Suparno \& Paul 2005). In other words, students believe the concept they have is correct and in accordance with the facts they see in the field even though in reality the concept is wrong according to expert judgment. This is what distinguishes students who experience misconceptions and students who do not understand concepts.

Demirci (2005) perform research about misconception in physics using a web-assisted physics program. Kuczmann (2017), states that misconceptions in physics attest the lack of recognition of existing physical correlations but improper ideas can often be found in their place. Alwan (2011) find that most of the students at education faculty of Al Fateh University, held alternative conceptions of heat and temperature. Handika et. al. (2015) thought that Physics is a subject that difficult to understand by the students. In learning physics, students have to use mathematical, symbols and intuition language influence to construct student's conception. Al-rsa'I, et.al. (2020), conducted research about misconception in physics in Jordan. Myneni et al. (2013) Students tend to retain nar ve understandings of concepts such as energy and force even after completing school andenteringcollege. Aufschnaiter (2010), make difference between misconception and missing conception using several student's cases in Germany.

The misconceptions presented by students occurred in almost all material in physics subjects. The results of research by Kaniawati et.al. (2019) show that $66.0 \%$ of students experience misconceptions on the concept of Newton's law. As many as 39.9\% of students experience misconceptions on the concept of dynamic electricity (Ismail, et.al. 2015). In light material, 26.2\% of students experienced misconceptions (Wahyuni, et.al. 2018). Likewise, on the temperature and heat material $12.9 \%$ of students experience misconceptions (Lestari, et. Al. 2015). From some of the results of these studies show that, students experience misconceptions in almost all material in physics subjects.

Misconceptions that occur in students can occur in multiple representations. The representation that is meant here can be in the form of pictures, words, graphics, mathematical formulations, and so on.
Pictures serve to visualize phenomena that occur in nature. Students' errors in visualizing an abstract event that exists in their cognitive structure through pictures indicate misconceptions or misconceptions in students. Likewise, when students misinterpret the graph, but students feel that their interpretation is correct also shows symptoms of misconceptions.

In general, student misconceptions can be caused by several factors, namely; students themselves, teachers, learning resources, context, and teaching methods (Suparno \& Paul 2005). Misconceptions caused by students can occur because students build their understanding based on experience, inadequate initial knowledge, incomplete reasoning, and wrong intuition so that their construction of understanding is different from that of experts (Barke, Al Hazari, \& Yitbarek, 2009). Students' mistakes in making observations and experiments can also cause misconceptions in students.

In addition, teacher errors in teaching, wrong teacher conceptions, and inadequate understanding of teachers can also cause misconceptions in students. Misconceptions caused by teacher errors are usually somewhat difficult to correct because students feel confident that the concepts taught by their teachers are correct. Thus, before teaching in class, the teacher should really master the material to be taught.

The teacher's big role in forming students' conceptions seems to need attention. The concern that is emphasized here is related to the conception of the teacher, whether the conception held by the teacher or prospective teacher is correct. Therefore, it is necessary to identify the conceptions that prospective teachers have before they actually go to school.

\section{Method}

The method used in this research is descriptive research method. Descriptive research is research to provide a description of the symptoms, phenomena, or facts under study by describing the value of the variable without intending to compare (Musfiqon, 2012). The main purpose of descriptive research is to make a systematic and accurate description or description of the facts being investigated.

The sample consisted of 25 students as prospective physics teachers at a university in the city of Mataram. The instrument used in this study was a three-tier test in the form of a multiple choice test with open reasons. The reason the test instrument is made open is so that students can more freely describe the understanding that exists in their cognitive structures. A total of 40 items were used in this study. These questions are classified into three forms of 
representation, namely verbal, figural and graphical. This aims to determine the distribution of the prospective physics teacher's misconceptions on each representation, especially in the material of straight motion and parabolic motion. Before being used, the test instrument is validated by an expert. This validation aims to see the suitability between the contents of the instrument and the material that has been taught, the suitability of questions and answers, and the suitability of grammar.

The test result data were then analyzed and categorized to determine student conceptions. The categorized data were analyzed using descriptive statistics by calculating the percentage of students who experienced misconceptions, understood concepts, and did not understand the concepts in each representation.

The following is a guideline for categorizing student conceptions using a three-tier test (Arslan, Cigdemoglu, \& Moseley, 2012).

Table 1. Guidelines for categorizing student conceptions using a three tier test.

\begin{tabular}{|c|c|c|c|c|}
\hline No & Answers & Reason & Confidence & Category \\
\hline 1 & True & True & Sure & $\begin{array}{l}\text { Scientific } \\
\text { Knowledge }\end{array}$ \\
\hline 2 & True & Wrong & Sure & Misconception \\
\hline 3 & Wrong & True & Sure & Misconception \\
\hline 4 & Wrong & Wrong & Sure & Misconception \\
\hline 5 & True & True & Unsure & Guessing \\
\hline 6 & True & Wrong & Unsure & Lack of Knowledge \\
\hline 7 & Wrong & True & Unsure & Lack of Knowledge \\
\hline 8 & Wrong & Wrong & Unsure & Lack of Knowledge \\
\hline
\end{tabular}

\section{Result and Discussion}

Based on the results of data analysis, it is obtained an overview of the conceptions of prospective teacher students if classified based on the electrical submaterial, namely as follows.

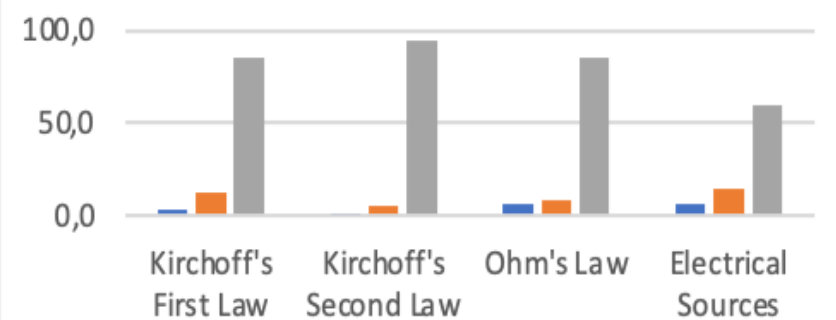

Misconception $\quad$ Scientific Knowledge

- Lack of Knowledge

Figure 2. Profile of student conception based on electricity sub-material
Figure 2 is representation of data shown on Table 2 consist of three main subjects on electricity.

Table 2: Profile of student conceptions viewed from various subjects

\begin{tabular}{llll} 
Subjects & $\begin{array}{l}\text { Mis- } \\
\text { conception }\end{array}$ & $\begin{array}{l}\text { Scientific } \\
\text { Knowledge }\end{array}$ & $\begin{array}{l}\text { Lack of } \\
\text { Knowledge }\end{array}$ \\
\hline $\begin{array}{l}\text { Kirchoff's First } \\
\text { Law }\end{array}$ & 2.9 & 11.9 & 85.2 \\
$\begin{array}{l}\text { Kirchoff's Second } \\
\text { Law }\end{array}$ & 0.3 & 5.2 & 94.5 \\
Ohm's Law & 6.5 & 8.3 & 85.2 \\
Electrical Sources & 6.5 & 14.1 & 79.4 \\
\hline
\end{tabular}

From the graph above, it shows that students experience misconceptions in all electricity submaterials. The biggest misconception occurs in the material of the Kirchof's second law and the misconception on the material sources of electric current with the same number, namely $6.5 \%$, and the smallest misconception occurs in the Kirchoff's first law, which is $0.3 \%$, and the rest is categorized as a lack of knowledge.

Most of the misconceptions and misconceptions that occur in students are because students are still unable to distinguish between the Kirchoff's second law concept and true. Students' understanding of these concepts is often because students do not understand the complete concept of real valtage, even though they already understand the difference in tension. They do not really understand the physical meaning of these concepts. In addition, students also do not really understand the concept of decreasing and increasing voltage due to electric currents in certain directions.

The conception profile of students if classified based on the type of question representation is as follows.

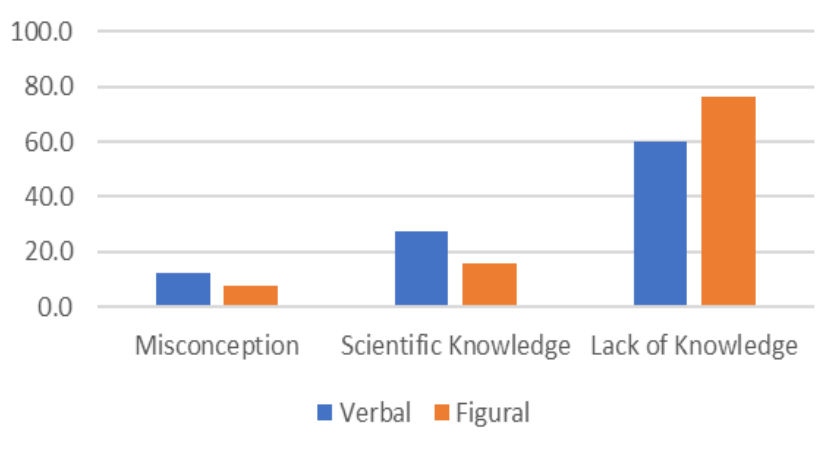

Figure 3. Profile of student conception when viewed from various representations

The graph in Figure 3 is a representation of Table 3 below consist of two categories. 
Table 3: Profile of student conceptions viewed from various representations

\begin{tabular}{llll}
\hline Category & Misconception & $\begin{array}{l}\text { Scientific } \\
\text { Knowledge }\end{array}$ & $\begin{array}{l}\text { Lack of } \\
\text { Knowledge }\end{array}$ \\
\hline Verbal & 12.3 & 27.7 & 60.0 \\
Graphical & 7.9 & 15.8 & 76.3 \\
\hline
\end{tabular}

The graph above shows that misconceptions and not understanding the concept mostly occur in the type of graphical questions, which is $84.2 \%$ totaled. This data shows that the student's ability to solve figural questions is very low. Students' ability to understand electrical circuit images is still very low.

To find out the profile of student misconceptions in more depth and their causes, the researcher will try to identify and describe the location of student misconceptions based on the question items given. In the subject of Kirchoff's first law , most students do not understand simple closed electrical circuits and their relationship to the valtage difference at each endpoint of the resistance.

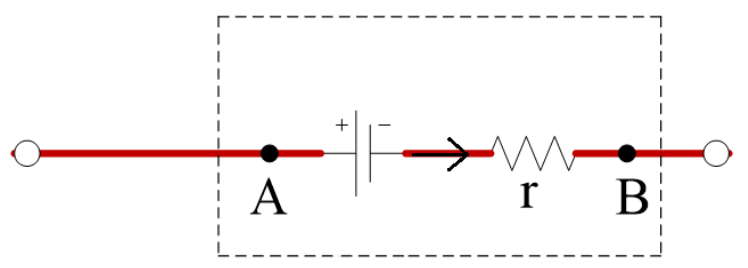

Figure 4. A battery and the direction of current in the battery

Students do not understand the correct direction of electric current in a battery in an electrical circuit as shown in figure 1 . There are still many students who think that the electric current in the battery flows from the positive pole to the negative pole. Whereas in fact the electric current flowing from the positive pole to the negative pole is only true if it occurs in the circuit outside the battery, while inside the battery the electric current flows from the negative pole and the positive pole.

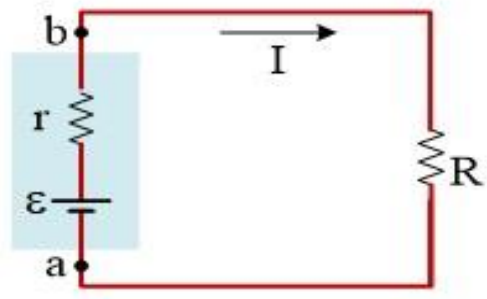

Figure 5. A simple closed circuit

In Kirchoff's second law subjects, students have not been able to understand simple closed circuits on figure 5, let alone compound circuits. They do understand that the voltage difference between the ends of the resistor is directly proportional to the strength of the electric current and is also directly proportional to the amount of resistance. However, they do not understand the relative valtage between the two ends of the resistance.

If ordered to calculate the voltage between the ends of the resistance they can do, but do not understand which voltage is greater and which is smaller, so when dealing with a closed circuit as shown in figure 6, they are unable to analyze the voltage on each points in the circuit.

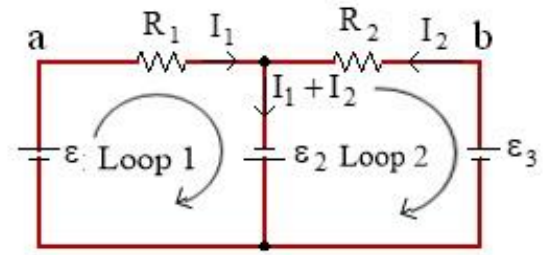

Figure 6. Complex circuit with two sources of electric current

In law material, students generally know the valtage difference but do not understand which one is greater and which is smaller

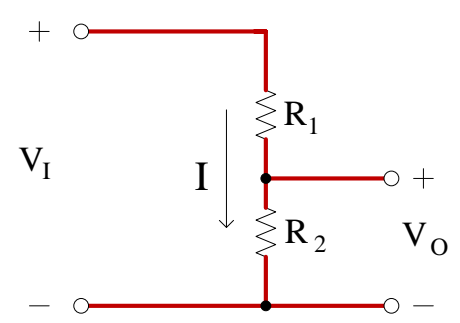

Figure 7. A resistor that is given an electric current

In Figure 7, students can generally calculate the valtage difference at point + and -, but do not understand the relative valtage at these points. This problem will lead students to misconceptions about relative valtage so that they cannot solve the problem in Kirchoff's second law.

In the subject of electric current sources, students do not understand the fundamental difference between the effective voltage of the maximum alternating voltage. Many students also do not understand the basic difference between an AC current source and a DC current source. They also generally do not understand about the generation of voltages in alternating current.

\section{Conclusion}

The research aims to identify the location of student physics teacher misconceptions on the subject of straight motion and parabolic motion in terms of 
various representations. Based on the results of the study showed that as many as $67 \%$ of students experienced misconceptions in the concept of straight motion, $53 \%$ of students experienced misconceptions on the concept of vertical motion, and $57 \%$ of students experienced misconceptions on parabolic motion. When viewed based on the representation, as many as $61 \%$ of misconceptions on verbal questions, $59 \%$ on figural questions, and $61 \%$ on graphic questions.

The results of this study indicate that the misconceptions that occur in students are classified as large in all concepts in the material of straight motion and parabolic motion. Therefore, it is necessary to improve the quality of learning in the classroom. One of the alternatives offered by the researcher as an effort to reduce misconceptions that occur in students is to use a multi-representation approach in learning.

In this study, the material used is limited to straight motion material and parabolic motion. Therefore, researchers suggest that further researchers identify student misconceptions on other material whether they get the same or different results. In addition, researchers also suggest that future studies use other types of tests (other than the three-tier test) to see if they get different results when compared to when using the three tier test.

\section{Acknowledgements}

Special thanks to Prof. Dr. Joni Rokhmat, M.Si. for further discussion on the subjects of misconception.

\section{References}

Al-rsa'I, M. S., Khosman, J. M., Tayeh, K. A., (2020). Jordanian Pre-Service Physics Teacher's Misconceptions about Force and Motion. Journal of Turkish Science Education. 17(4).

Alwan, A.A. (2011), Misconception of heat and temperature Among physics students, International Conference on Education and Educational Psychology (ICEEPSY 2010).

Arslan, H. O., Cigdemoglu, C., Moseley, C. (2012). A Three-Tier Diagnostic Test to Assess Pre-Service Teachers' Misconceptions about Global Warming, Greenhouse Effect, Ozone Layer Depletion, and Acid Rain. International Journal of Science Education, 34(11), 1667-1686. doi: 10.1080/09500693.2012.680618

Aufschnaiter, C.V. and Rogge, C. (2010) Misconceptions or Missing Conceptions? Eurasia Journal of Mathematics, Science E Technology Education, 6(1), 3-18
Barke, H.D., Al Hazari, Yitbarek, S. (2009). Misconceptions in Chemistry. Addressing Perceptions in chemical Education. Berlin: Springer.

Demirci, N, (2005), A Study About Students' Misconceptions In Force And Motion Concepts By Incorporating A Web-Assisted Physics Program, The Turkish Online Journal of Educational Technology - TOJET. 4(3)

Gafoor, A.K., Akhiles, P.T. (2008), Misconception in Physics at Secondary School Students, Journal of Indian Eduction, 34(1), 77-90

Handhika, J., Cari, Suparmi, Sunarno, W., (2015), Exsternal Representation To Overcome Misconception In Physics, International Conference on Mathematics, Science, and Education 2015 (ICMSE 2015).

Herron, J.D., Canty, L.L., Ward, R., and Srinwan, V. (1977). Problem with Concept Analysis. Science Education, 61, 185-199.

Hikmawati, Sutrio. (2019). Miskonsepsi dalam Fisika. Selong: Garuda Ilmu. [Indonesian]

Ismail, I. I., Samsudin, A., Suhendi, E., Kaniawati, I. (2015). Diagnostik Miskonsepsi Melalui Listrik Dinamis Four Tier Test. Prosiding Simposium Nasional Inovasi dan Pembelajaran Sains (SNIPS 2015), Bandung-Indonesia. 381-384. Retrieved from:

https://www.researchgate.net/publication/301 523361_Diagnostik_Miskonsepsi_Melalui_Listrik _Dinamis_Four_Tier_Test

Kaniawati, I. (2017). Pengaruh Simulasi Komputer Terhadap Peningkatan Penguasaan Konsep Impuls-Momentum Siswa SMA. Jurnal Pembelajaran Sains, 1,(1), 24-26. Retrieved from: http://journal2.um.ac.id/index.php/jpsi/article /view/637 [Indonesian]

Kaniawati, I., Fratiwi, N.J., Danawan, A., Suyana, I., Samsudin, Suhendi, E. (2019). Analyzing Students' Misconceptions about Newton's Laws through Four-Tier Newtonian Test (FTNT). Journal of Turkish Science Education, 16 (1), 110122.

Kuczmann, I (2017), The structure of knowledge and students' misconceptions in physics, AIP Conference Proceedings 1916, 050001 (2017); https://doi.org/10.1063/1.5017454

Lestari, P.A.S., Rahayu, S., Hikmawati (2015). Profil Miskonsepsi Siswa Kelas X SMKN 4 Mataram pada Materi Pokok Suhu, Kalor, dan Perpindahan Kalor. [Indonesian]

Myneni, L. S., Narayanan, N.H., Rebello, S., Rouinfar, A, and Pumtambekar, S., (2013), An Interactive and Intelligent Learning System for Physics Education. IEEE transactions on learning technologies, 6(3). 